\title{
Occurrence and Analysis of Apple Blotch-like Symptoms on Apple Leaves
}

\author{
Chang-Gi Back ${ }^{1,4}$, Seung-Yeol Lee ${ }^{1}$, In-Kyu Kang ${ }^{2}$, Tae-Myung Yoon ${ }^{2}$, and Hee-Young Jung ${ }^{1,3^{*}}$ \\ ${ }^{1}$ School of Applied Biosciences, Kyungpook National University, Daegu 702-701, Korea \\ ${ }^{2}$ Department of Horticultural Science, Kyungpook National University, Daegu 702-701, Korea \\ ${ }^{3}$ Institute of Plant Medicine, Kyungpook National University, Daegu 702-701, Korea \\ ${ }^{4}$ Horticultural and Herbal Crop Environment Division, National Institute of Horticultur and Herbal Science (RDA), Wanju 565-852, Korea
}

\begin{abstract}
Apple blotch-like symptoms (ABLS) were observed on 'Fuji' apple leaves in Cheongsong, Gunwi and Yeongcheon apple orchards located in Gyeongbuk Province during 2010-2014. Characteristics of ABLS were yellowing, brown spots on leaves, and defoliation, similar to apple blotch diseased (ABD) leaves, which are infected with Marssonina coronaria. It is difficult to differentiate by eye between ABLS and ABD, which has led to misdiagnosis and overuse of fungicides. The present study was conducted to investigate the cause of ABLS using stereomicroscopy, culture isolation, cross-sectional analysis of leaves, and PCR. No acervuli were found on the surface of ABLS leaves and no growth was observed on potato dextrose agar (PDA) plates in culture. Furthermore, cross-sectional analysis revealed similar results, and mycelia were absent in ABLS leaves. By contrast, all these characteristics were present in ABD leaves. Furthermore, no fungi or viruses were detected in ABLS leaves by PCR, suggesting that the disease is not caused by these agents. These findings suggest that ABLS might be a physiological disorder in plants that is distinct from ABD.
\end{abstract}

Additional key words: acervuli, apple blotch disease, 'Fuji' apple, M. coronaria, stereomicroscopy

\section{Introduction}

According to the Korean Society of Plant Pathology, approximately 41 apple diseases have been reported in Korea (Kim et al., 2009). Among these, 32 are caused by fungal plant pathogens. The major apple leaf diseases are apple blotch caused by Marssonina coronaria, alternaria leaf spot caused by Alternaria mali, gray mold caused by Botrytis cinerea, rust caused by Gymnosporangium yamadae, powdery mildew caused by Podosphaeria leucotricha, silver leaf caused by Stereum ourpureum, and leaf spot caused by Leptosphaeria sp. These diseases damage apples leaves and affect fruit quality and yield. However, among these diseases the mosteconomically important in Korean orchards are apple blotch and alternaria leaf spot (Lee et al., 2007). Apple blotch diseases caused by $M$. coronaria have been reported in many countries including Korea (Lee and Shin, 2000; Sharma, 2000; Tamietti and Matta, 2003; Lee et al., 2011). Furthermore, Korean isolates were very similar to Japanese and Chinese isolates, where the disease has caused a significant production problem over the past few years (Lee et al., 2011). According to previous reports, the leaves are the main photosynthetic organs in plants, and as such, are closely associated with photosynthetic function. Apple leaves produce sucrose and starch as the primary products of photosynthesis, which affect fruit quality and plant vigor. The allocation and distribution of carbon resources from leaves plays a key role in how these resources are used in sink tissues like fruit, where they can affect downstream traits like fruit quality (Gianni et al., 2006). Therefore, many farmers use fungicides to manage and control leaf diseases. Important research has focused on the intensive management

\footnotetext{
*Comesponding author: heeyoung@knu.ac.kr
}

※ Received 26 October 2014; Revised 23 January 2015; Accepted 29 January 2015. This research was supported by "Cooperative Research Program for Agriculture Science \& Technology Development (Project No. PJ010481032014)" Rural Development Administration, Republic of Korea and "Advanced Production Technology Development Program (Project No. 314031-3)" iPET (Korea Institute of Planning and Evaluation for Technology of Food, Agriculture, Forestry, and Fisheries). 
of these diseases through the development of a fungicidal spraying program (Lee et al., 2009).

During 2010-2014, apple blotch-like symptoms (ABLS) were observed on 'Fuji' apple leaves in several apple orchards located in Gyeongbuk Province, Korea. ABLS are characterized by the progressive yellowing of leaves, the appearance of brown and green spots, and defoliation of leaves, which are very similar to those observed in apple blotch diseased (ABD) leaves as a result of $M$. coronaria infection. Therefore, farmers misdiagnosed this disease and almost all cultivation areas were sprayed with fungicide several times from May to early June to control ABLS. However, fungicides were unable to control the ABLS. Furthermore, it was difficult to differentiate between these two diseases by eye. The only observable distinction of apple ABLS was its lack of dissemination ability in orchards, unlike ABD. However, there have been no previous reports on ABLS in Korea. Therefore, this study was conducted to investigate the cause of ABLS and to enable its distinction from ABD by eye, by microscopic and molecular methods.

\section{Materials and Methods}

\section{Collection of Samples and Stereomicroscopy}

Abnormal yellow leaves having brown and green spots were collected from 30 apple orchards located in Cheongsong, Gunwi, Yeongcheon in Gyeongbuk Province during 2010-2014. Over 70 samples were collected from each orchard, and were all visibly similar and difficult to differentiate from ABD leaves by eye. To observe the external leaf surface, approximately 30 samples of both ABLS and ABD leaves were examined under stereomicroscope (Dimis-M, Korea).

\section{Culture Isolation and Light Microscopy}

For culture isolation of $\mathrm{ABLS}$ and $\mathrm{ABD}$, we cut the infected lesion, including brown spots, out of leaves into small pieces (3-5 mm) and surface sterilized in $70 \%$ ethanol and $1 \%(\mathrm{v} / \mathrm{v})$ sodium hypochloride for $30 \mathrm{~s}$, each followed by three rinses with sterilized distilled water (SDW). Dried pieces were placed on PDA plates and incubated at $25^{\circ} \mathrm{C}$ in the dark for 3 days. To examine the internal leaf structure, samples were fixed (Karnovsky's fixative) and dehydrated in an ethanol series. Next, samples were infiltrated (propylene oxide) and polymerized in Spurr's resin at $70^{\circ} \mathrm{C}$ for $8 \mathrm{~h}$. After polymerization, $3 \mu \mathrm{m}$ semi-thin sections were cut using an ultra-microtome (MT-7000, RMC), stained with methylene blue, and examined under a light microscope (BX-50, Olympus, Japan).

\section{DNA Extraction and PCR Amplification}

To perform PCR, total DNA was extracted from infected leaves using the cetyltrimethyl ammonium bromide (CTAB) method (Namba et al., 1993). The PCR primer set, MarM-for (5'-GCT TAT TCT TGG CAA GCC-3')/Mar-M-rev (5' -CAC AGT CTT GGA GCA TCG-3') was disigned from partial of putative sequences of the metallopeptidase gene with a predicted PCR product of $250 \mathrm{bp}$. Amplification reactions were performed using a thermal cycler 9700 (Applied Biosystems, Foster City, CA, USA) with the following program: an initial denaturation stage of $3 \mathrm{~min}$ at $94^{\circ} \mathrm{C}$, followed by 30 cycles of denaturation for $30 \mathrm{~s}$ at $94^{\circ} \mathrm{C}$, annealing for $30 \mathrm{~s}$ at $60^{\circ} \mathrm{C}$, extension for $30 \mathrm{~s}$ at $72^{\circ} \mathrm{C}$, and a final 3 min extension at $72^{\circ} \mathrm{C}$. Amplified PCR products were electrophoresed on a $1 \%$ agarose gel using a 100-bp Plus DNA ladder as a marker, stained with ethidium bromide, and visualized on a UV transilluminator.

\section{RT-PCR Amplification}

Total RNA was extracted from abnormal yellow leaves with brown spots using an RNeasy mini kit (Qiagen, USA), according to the manufacturer's protocol. RT-PCR was then conducted to detect apple chlorotic leaf spot virus (ACLSV), apple stem pitting virus (ASPV), apple stem grooving virus (ASGV), apple mosaic virus (ApMV) and apple skin viroid (ASSVd) using specific primers pairs, and conditions were adjusted as previously reported (Menzel et al., 2002; Shim et al., 2006; Hassan et al., 2006; Lee et al., 2001). RT-PCR was conducted using an Applied Biosystems 2720 Thermal Cycler (Applied Biosystems, USA) with AccuPower ${ }^{\circledR}$ RT-PCR Premix (Solgent, Daejeon, Korea). The RT-PCR products were then electrophoresed on a $1.5 \%$ agarose gel, stained with ethidium bromide, and visualized under UV light.

\section{Results and Discussion}

\section{Symptomatic Comparison between ABLS and ABD Leaves}

ABLS were observed on several farms located in Gyeongbuk Province during 2011-2014. Brown and dark brown spots appeared on infected leaves and led to their discoloration from green to yellow, and caused defoliation in early June (Fig. 1A-H). These symptoms are very similar to those of ABD, which also causes small black or brown spots to develop on the surface of leaves, causing discoloration and defoliation of apple leaves (Fig. 1I-L). The only difference was the formation of acervuli on ABD leaves. These acervuli were black and greenish in color and were observed only on ABD leaves. From the above observation, it was concluded 
that ABD and ABLS were very similar diseases, although it is difficult to differentiate between the two by eye. However, the presence of acervuli on ABD leaves enables us to differentiate between these two similar diseases by morphology alone.

\section{Cultural Isolation and Microscopic Observation}

In the culture isolation method, ABLS and ABD leaves generated very different results and no pathogen was isolated from ABLS leaves cultured on PDA media (data not shown). However, in the case of ABD leaves, M. coronaria grew

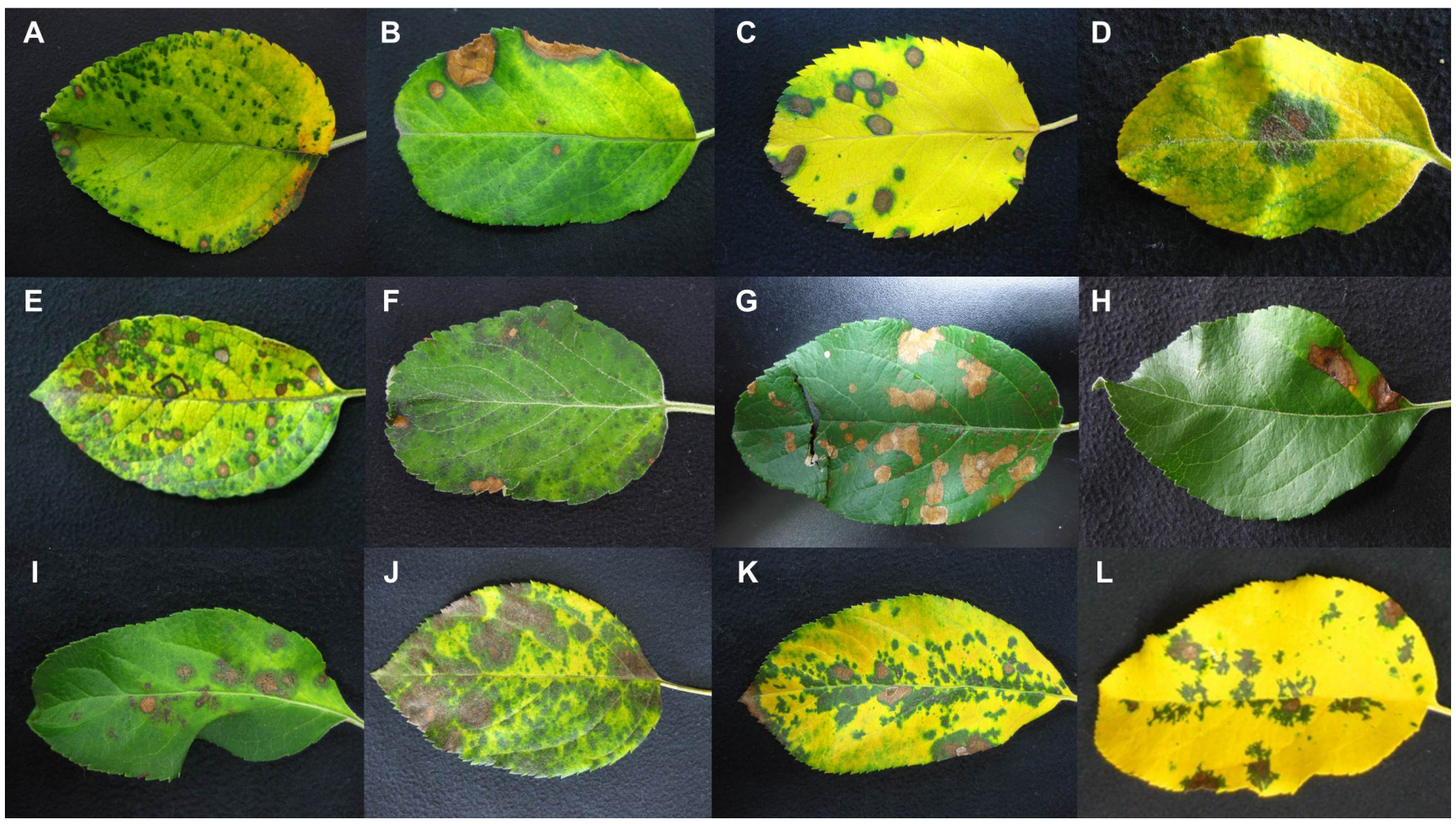

Fig. 1. Comparison of leaves with apple blotch disease and apple blotch-like symptom: A-H, apple blotch-like symptom leaves; I-L, apple blotch-diseased leaves.

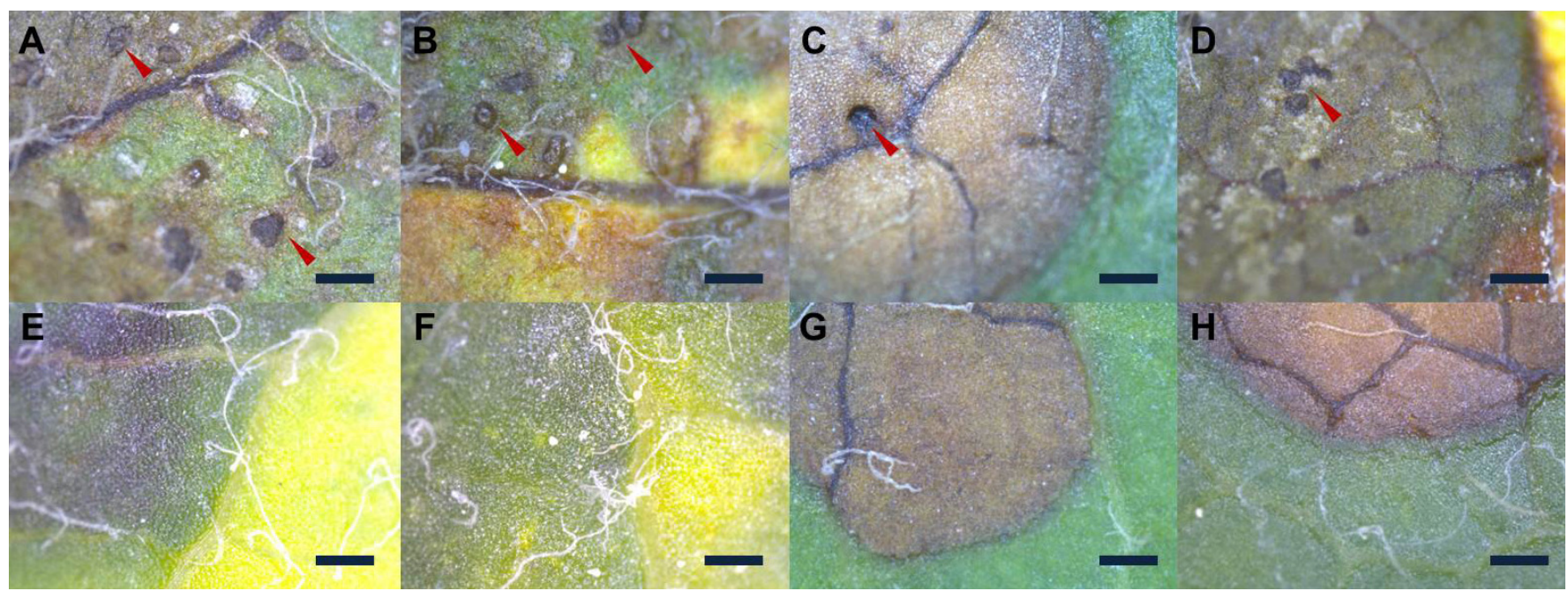

Fig. 2. Stereomicrographs of leaves with apple blotch disease and apple blotch-like symptoms: A-D, apple blotch diseased; E-H, apple blotch-like symptoms. Red arrowheads indicate acervuli. Scale bar indicates $500 \mu \mathrm{m}$. 
well on PDA media and was successfully isolated (data not shown). The microscopic study of abnormal ABLS and $A B D$ leaves revealed very different morphologies caused by the two diseases. Typical apple blotch symptoms were observed on ABD leaves, which displayed brown spots that were actually acervuli on the external surface of leaves as previously reported (Lee et al., 2011; Back and Jung, 2014). However, the ABLS leaves also developed brown spots, although no acervuli were found on the surface of infected leaves (Fig. 2E-H). A similar disease as similar symptoms,having irregular, brown, necrotic areas between veins with no acervuli was reported (Sutton and Sanhueza, 1998; Table 1). According to Sutton and Sanhueza (1998), the disease has been given many common names, including Golden Delicious leaf blotch, necrotic leaf spot, physiological leaf spot, and necrotic leaf blotch. In our study, similar leaf spots were observed for the first time in 'Fuji' apple orchards in Korea. The microscopic observation of the internal leaf structure showed contrasting results after comparing cross sectional images of ABLS and ABD leaves. Large numbers of mycelia-like structures were observed in ABD leaves, which is evidence of $M$. coronaria infection (Fig. 3A-B). However, in ABLS leaves, mycelia-like structures were absent and a dense green structure was observed

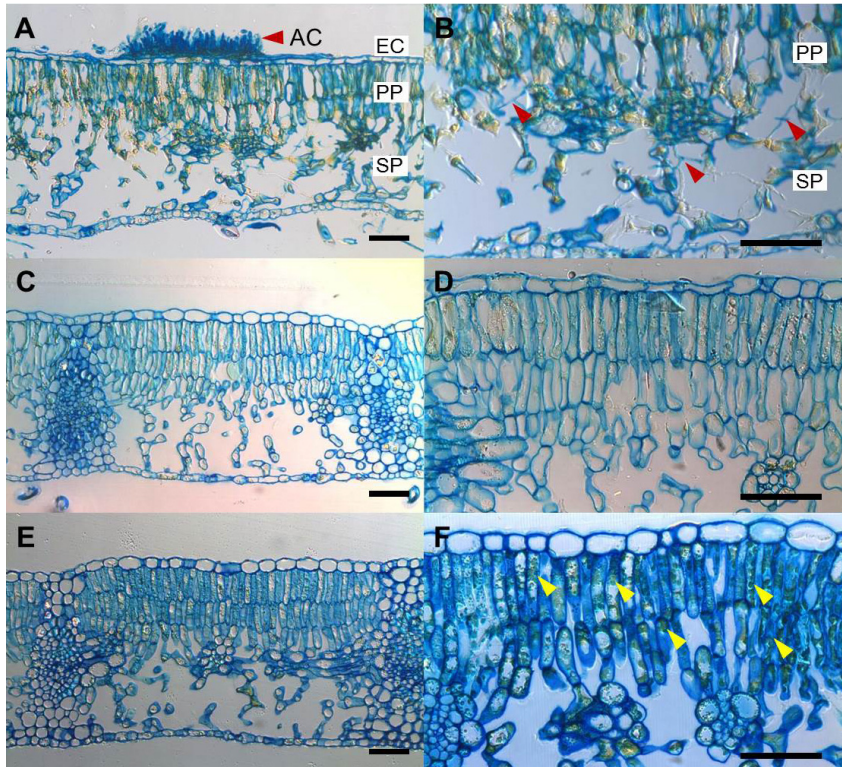

Fig. 3. Cross-sectional images of leaves with apple blotch disease and apple blotch-like symptoms: A-B, apple blotch diseased; C-F, apple blotch-like symptoms. EC, epidermal cell; PP, palisade parenchyma; SP, spongy parenchyma; AC, acervuli. Red arrowhead, mycelium-like structure; yellow arrowhead, dense green structure. Scale bar indicates 50 $\mu \mathrm{m}$.

Table 1. Comparison of apple blotch-like symptoms (ABLS) with other leaf spot diseases.

\begin{tabular}{|c|c|c|c|c|c|c|}
\hline & Symptoms & Causal agent & Period & Country & Cultivar & Reference \\
\hline $\begin{array}{l}\text { Apple blotch-like } \\
\text { symptoms }\end{array}$ & $\begin{array}{l}\text { Light brown spots } 3-10 \\
\text { mm, yellow leaf, leaf fall }\end{array}$ & Unknown & $\begin{array}{l}\text { May to } \\
\text { June }\end{array}$ & South Korea & Fuji & $\begin{array}{l}\text { Present } \\
\text { study }\end{array}$ \\
\hline Apple blotch & $\begin{array}{c}\text { Dark green circular patches, black small } \\
\text { acervuli, }(0.08-0.4 \mathrm{~mm}), \text { premature } \\
\text { defoliation }\end{array}$ & $\begin{array}{l}\text { Marssonina } \\
\text { coronaria }\end{array}$ & $\begin{array}{l}\text { May to } \\
\text { October }\end{array}$ & $\begin{array}{l}\text { Korea, } \\
\text { Japan, } \\
\text { China, India, } \\
\text { Europe }\end{array}$ & $\begin{array}{l}\text { Fuji, } \\
\text { Hongro, } \\
\text { Gamhong }\end{array}$ & $\begin{array}{l}\text { Lee et al., } \\
2011\end{array}$ \\
\hline $\begin{array}{l}\text { Alternaria leaf } \\
\text { spot }\end{array}$ & $\begin{array}{l}\text { Small, round, purplish or blackish spots } \\
(1.5-5 \mathrm{~mm}) \text {, } \\
\text { irregular and much darker, acquiring } \\
\text { a "frog-eye" appearance }\end{array}$ & Alternaria mali & $\begin{array}{l}\text { May to } \\
\text { October }\end{array}$ & Worldwide & $\begin{array}{l}\text { Fuji, } \\
\text { Hongro, } \\
\text { Gamhong }\end{array}$ & $\begin{array}{l}\text { Yoder and } \\
\text { Biggs, } 1998\end{array}$ \\
\hline Frog-eye leaf spot & $\begin{array}{l}\text { Round dark brown spot }(2-5 \mathrm{~mm}) \text { in } \\
\text { diameter, black border and tan center } \\
30-50 \text { spots }\end{array}$ & $\begin{array}{l}\text { Botryosphaeria } \\
\text { obtusa }\end{array}$ & No data & No data & $\begin{array}{l}\text { Golden } \\
\text { delicious }\end{array}$ & $\begin{array}{c}\text { Rosenberger, } \\
2001\end{array}$ \\
\hline Leaf spot & $\begin{array}{l}\text { Irregular, light tan spots }(3-12 \mathrm{~mm}) \text {, } \\
\text { severe leaf abscission, only a few } \\
\text { conidia are produced on the surface }\end{array}$ & $\begin{array}{l}\text { Glomerella } \\
\text { cingulate }\end{array}$ & No data & $\begin{array}{l}\text { Brazil, } \\
\text { Europe }\end{array}$ & $\begin{array}{l}\text { Gala, } \\
\text { Golden } \\
\text { delicious }\end{array}$ & $\begin{array}{l}\text { Sutton and } \\
\text { Sanhueza, } \\
1998\end{array}$ \\
\hline $\begin{array}{l}\text { Leaf spot and leaf } \\
\text { drop }\end{array}$ & $\begin{array}{l}\text { Irregularly shaped, well-defined, } \\
\text { brown necrotic spots }(1-20 \mathrm{~mm})\end{array}$ & $\begin{array}{l}\text { Rootstock, climatic } \\
\text { factor Soil factor } \\
\text { nutrition, Tree age } \\
\text { fungicide }\end{array}$ & $\begin{array}{l}\text { July, } \\
\text { August, } \\
\text { September }\end{array}$ & Netherlands & $\begin{array}{l}\text { Golden } \\
\text { delicious }\end{array}$ & $\begin{array}{l}\text { Jonkers, } \\
1973\end{array}$ \\
\hline $\begin{array}{l}\text { Necrotic leaf } \\
\text { blotch }\end{array}$ & $\begin{array}{l}\text { Irregular brown blotches, }(5-15 \mathrm{~mm}) \text {, } \\
\text { blotches are restricted to leaf vein }\end{array}$ & $\begin{array}{l}\text { Unknown, } \\
\text { No fungal } \\
\text { bacterial, other } \\
\text { type of pathogens }\end{array}$ & $\begin{array}{l}\text { July, } \\
\text { August }\end{array}$ & USA & $\begin{array}{l}\text { Golden } \\
\text { delicious }\end{array}$ & $\begin{array}{l}\text { Babadoost, } \\
\text { 1984; Ellis, } \\
2008\end{array}$ \\
\hline
\end{tabular}




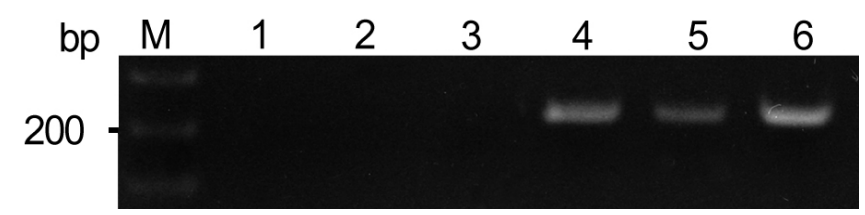

Fig. 4. $P C R$ amplification of $M$. coronaria: lanes 1-3, leaves with apple blotch-like symptoms; lanes 4-6, apple blotch diseased leaves; M, 100 bp DNA ladder.

on the palisade parenchyma (Fig. 3C-F). Similar to the culture isolation method, cross-sectional analysis also showed that $M$. coronaria was not the causal agent of ABLS, because from microscopic observation it was confirmed that no acervuli or hypha exist on the surface of ABLS-infected leaves (Fig. 2E-H). Similarly, no mycelium was observed on the inner surface of ABLS leaves (Fig. 3C-F).

\section{PCR and RT-PCR Analysis}

PCR and RT-PCR methods were used for the first time to observe ABLS infection and to compare it with diseases with known causal agents, such as $M$. coronaria and viruses. Our data revealed a 250-bp DNA fragment that was amplified from ABD leaves, whilst this fragment was not amplified from ABLS leaves (Fig. 4). Although, ABLS leaves have different characteristics from virus-infected leaves, due to the ambiguous characteristics of ABLS, we used RT-PCR to allow virus detection. However, similar results were observed using the RT-PCR detection method and no virus was detected in ABLS leaves (data not shown). Therefore, our results are similar with previous reports that this disorder is not caused by fungus or other known pathogen, and thus the abiotic cause of this disease remains unknown (Ellis, 2008; Table 1). Moreover, previous reports have suggested that abiotic causes such as air pollution and nutrient deficiencies do not appear to be involved (Jonkers, 1973; Kenderand andSpierings, 1975). Evidence suggests that the disease may be associated with a rapid synthesis of gibberellins that is triggered by a combination of environmental factors, including low light intensity, cool temperatures, and high soil moisture (Sutton and Clayton, 1974; Jonkers, 1973).

The present results confirm that ABLS is very different from $A B D$, and it may represent aphysiological disorder in plants. ABLS resulted in symptoms similar to previously reported leaf spot diseases caused by different pathogens (Yoder and Biggs, 1998; Rosenberger, 2001; Sutton and Sanhueza, 1998). The present results are also parallel with previous reports that leaf blotch begins as a pale green area in the leaf that turns to brown (Jonkers, 1973; Table.
1). According to this report, these blotches vary in size from $5 \mathrm{~mm}$ to several centimeters in diameter, and one to several blotches can occur on the same leaf (Table 1). The ABLS occurred in hot dry weather from May to June, which differs from the period in which the occurrence of other leaf spot diseases has been reported (Table 1). ABLS does not cause fruit drop or fruit blemishes. However, it may have adverse effects on fruit size because, from the present study, it was confirmed that ABLS infects the main photosynthetic organ of affected plants and causes defoliation in a very short time, which may disturb photosynthetic function.

According to previous reports apple that apple leaves produce starch as a photosynthetic product, which has great influence on fruit quality and plant vigor (Gianni et al., 2006). In our study, ABLS caused defoliation and previous studies have shown that this disease occurs in distinct periods or in waves and can result in up to $70 \%$ defoliation (Jonkers, 1973; Babadoost, 1984). Furthermore, ABLS is similar to leaf spot disease caused by physiological disorders or abiotic factors that also caused defoliation of leaves in a short period of time (Table 1). No studies have reported the effects of this disorder on fruit size, because it is not known how to maintain the affected and unaffected trees in the field to allow for parallel comparisons to be made. Although it appears that ABLS is not caused by a fungus or bacterium and the causal agent of this disorder is unknown. Sometime a positive correlation of ABLS with fertilizer overuse was found in different orchards. Therefore, the possible factors of ABLS in Korean orchards are the overuse of fertilizer, hot and hazy weather following a humid rainy period. Different varieties respond differently to fertilizer application and nutrient level. Fertilizers play a key role in orchard management and relation to the growth rate of leaves; sometime high magnesium and potassium level causes defoliation in apple orchards. Therefore, the formers should follow proper fertilizer program to manage the crop nutrition that may be helpful to control 'ABLS' in future.

\section{Literature Cited}

Babadoost, M. 1984. Necrotic leaf blotch of Golden Delicious apples. Report on plant disease. RPD No.817.

Back, C.G. and H.Y. Jung. 2014. Biological characterization of Marssonina coronaria infecting apple trees in Korea. Kor. J. Mycol. 42:183-190.

Ellis, M.A. 2008. Necrotic leaf blotch of Golden Delicious apples. The Ohio State University Extension. Fact Sheet HYG. p. 3204-3208. 
Gianni, T., S. Yasuo, L.U. Sandie, L. Bruce, O. Nichole, K.H. William, and T.M. DeJong. 2006. Silencing leaf sorbitol synthesis alters long-distance partitioning and apple fruit quality. Proc. Natl. Acad. Sci. doi:10.1073/pnas.0605873103.

Hassan, M., A. Myrta, and J. Polak. 2006. Simultaneous detection and identification of four pome fruit viruses by one tube pentaplex RT-PCR. J. Virol. Methods 133:124-129.

Jonkers, H. 1973. Review on leaf spot and leaf drop: A physiological disorder of the 'Golden Delicious' apple. Sci. Hortic. 1:231-237.

Kender, W.J. and F.H.F.G. Spierings. 1975. Effects of sulfur dioxide, ozone, and their interactions on 'Golden Delicious' apple trees. Neth. J. Plant Pathol. 81:149-151.

Kim, W.G., H.M. Koo, K.H. Kim, I.H. Hyun, S.K. Hong, J.S. Cha, Y.K. Lee, K.H. Kim, H.S. Choi, and D.G. Kim. 2009. List of plant diseases in Korea. 5th ed. Anyang: Kor. Soc. Plant Pathol.

Lee, D.H., C.G. Back, N.K.K. Win, K.H. Choi, K.M. Kim, I.K. Kang, C. Choi, T.M. Yoon, J.Y. Uhm, and H.Y. Jung. 2011. Biological characterization of Marssonina coronaria associated with apple blotch disease. Mycobiology 39:200-205.

Lee, D.H., H.C. Shin, R.H. Cho, and J.Y. Uhm. 2009. Reducing fungicidal spray frequency for major apple diseases by increasing thespray interval from 15 to 25 days. Plant Pathol. J. 25:270-279.

Lee, H.T. and H.D. Shin. 2000. Taxonomic studies on the genus Marssonina in Korea. Mycobiology 28:39-46.

Lee, J.H., J. K. Park, D.H. Lee, J.Y. Uhm, S.Y. Ghim, and J.Y. Lee. 2001. Occurrence of apple scar skin viroid-Korean strain (ASSVd-K) in apples cultivated in Korea. Plant Pathol. J. 17:300-304.
Lee, S.W., D.H. Lee, K.H. Choi, and D.A. Kim. 2007. A report on current management of major apple pests based on census data from farmers. Kor. J. Hort. Sci. Technol. 25:196-203.

Menzel, N., W. Jelkmann, and E. Maiss. 2002. Detection of four apple viruses by multiplex RT-PCR assays with coamplification of plant m-RNA as internal control. J. Virol. Methods 99:89-92.

Namba, S., S. Kato, S.Iwanamis, H. Oyaizu, H. Shiozawa, and T. Tsuchizaki. 1993. Detection and differentiation of plant-pathogenic mycoplasma-like organism using polymerase chain reaction. Phytopathology 83:786-791.

Rosenberger, D.A. 2001. Leaf spotting: causes and solutions. Proc. New England Fruit Growers Mtg., Sturbridge, USA.

Sharma, J.N. 2000. Marssonina blotch - a new disease of apple and its control. Indian J. Plant Prot. 28:100-101.

Shim, H.K., H.K. Hwang, C.K. Shim, S.W. Son, D.G. Kim, and S.C. Lee. 2006. The pear black necrotic leaf spot disease virus transmitted by Talaramyces flavus displays pathogenicity similar to apple stem grooving virus strain. Kor. J. Plant Pathol. 22:255-259.

Sutton, T.B. and C.N. Clayton. 1974. Necrotic leaf blotch of Golden Delicious apples. NC Agric. Exp. Bull. 224.

Sutton, T.B. and R.M.V. Sanhueza.1998. Necrotic leaf blotch of Golden Delicious-Glomerella leaf spot: a resolution of common names. Plant Dis. 82:267-268.

Tamietti, G. and A. Matta.2003. First report of leaf blotch caused by Marssonina coronaria on apple in Italy. Plant Dis. 87:1005.

Yoder, K.S. and A.R. Biggs. 1998. West Virginia University Extension Service Factsheets, WVU Extension Service. 